\title{
Prevalence of respiratory symptoms and sensitization by mould antigens among a group of maltworkers
}

\author{
H. F. V. RIDDLE \\ Ardclinis, Dysart, Fife KY1-2XL, Scotland
}

\begin{abstract}
Riddle, H. F. V. (1974). British Journal of Industrial Medicine, 31, 31-35. Prevalence of respiratory symptoms and sensitization by mould antigens among a group of maltworkers. The prevalence of allergic alveolitis, chronic respiratory symptoms, and sensitization by antigens from mould spores was investigated in 114 men employed at five maltings. Twentyfive carpet workers were used as a control group. Chronic respiratory symptoms were commoner among maltworkers than among the controls. One probable case of allergic alveolitis was discovered in a maltworker. More than half the maltworkers were found to have precipitating antibodies in their serum against antigens from mould spores of Aspergillus clavatus, Penicillium granulatum, Penicillium citrinum or Rhizopus stolonifer. There was no obvious correlation between sensitization to these and the presence of chronic respiratory symptoms.
\end{abstract}

French maltworkers, who were inhaling dense clouds of the spores of Aspergillus fumigatus and Mucor mucedo rising from mouldy barley being turned in the poorly ventilated and confined spaces of malt barns, developed a severe respiratory illness characterized by fever, breathlessness after work, a dry cough with little sputum, and loss of weight (ValleryRadot and Giroud, 1928). The serum of the affected men contained precipitating antibodies against antigens extracted from the moulds, and their skin reacted by an immediate wheal response followed some hours later by a brawny swelling to prick testing with these antigens. In an almost identical situation inhalation of the spores of Aspergillus clavatus caused an illness with similar features, and bronchial provocation tests confirmed the diagnosis of allergic alveolitis in a Scottish maltworker (Riddle et al., 1968). A year later the same authors recorded a further incident in another maltings (Channell et al., 1969).

A survey to test the hypothesis that allergic alveolitis and respiratory illness are common among maltworkers and are caused by precipitins to mould antigens inhaled at work is recorded below.

\section{Methods}

The survey was conducted among the 114 maltmen working in five separate maltings in Fife during the 1968 and 1969 malting seasons. Twenty-five male carpet workers, employed in very dusty work, were used as controls. The serological results were also contrasted with sera collected from 100 paper workers at a routine blood collection for the Blood Transfusion Service.

The investigation was divided into three parts.

\section{(1) Mycological survey}

Each maltings was visited on several occasions, and samples of mouldy malt and dust were collected. The moulds present were isolated and after identification three moulds, Penicillium granulatum, Penicillium citrinum, and Rhizopus stolonifer, found commonly in each of the maltings were chosen for routine screening together with the two strains of $A$. clavatus isolated in Fife and the East Lothians (Riddle et al., 1968; Channell et al., 1969). 
(2) Immunological survey

The five mould strains were grown separately in bulk and the antigens from the spore crop were extracted in pyridine acetate buffer and concentrated by elution through Sephadex G200 and lyophilization(Riddle, 1970). The presence of precipitating antibodies was detected by gel diffusion (Longbottom and Pepys, 1964).

The same antigens were used for skin testing after being sterilized by passage through a micropore filter.

\section{(3) Clinical survey}

Each man was interviewed using the standard Medical Research Council Questionary on Respiratory Symptoms (1966) with additional questions relating symptoms to work situations and times of occurrence related to work. Physical examination was restricted to the respiratory and cardiovascular systems unless the clinical history suggested that a fuller examination was necessary. Respiratory function was assessed using a wedge spirometer to record the forced expired volume in one second $\left(F E V_{1}\right)$ and forced vital capacity (FVC), and after collection of serum each man had a chest radiograph. Only the first 36 men were skin tested because of concern that the procedure might sensitize men who could subsequently be at risk if exposed to the antigens. The presence of persistent cough or the regular production of sputum for more than two consecutive months, with or without the presence of breathlessness or wheezing, were accepted as evidence of chronic respiratory illness with or without associated physical signs.

The data from these investigations were related to age, length of service in the maltings, smoking habits, immunological response, and other relevant factors such as the personal and family history of atopy. Recurrent respiratory symptoms were compared in maltworkers and carpet workers.

\section{Results}

Among the 114 maltmen and 25 carpet worker controls examined, eight of the maltmen had symptoms and signs of disabling respiratory disease. In none of these cases was it possible to relate the illness to their work, though one man (H.G.), who was asthmatic, has had very little time off work since finding a more sheltered occupation as night watchman in a recently built electronics factory. In addition to the eight there was one probable case of allergic alveolitis (J.C.). His symptoms had suggested an episode of acute bronchitis but he was found to have a high titre of precipitating antibodies against the $A$. clavatus antigen. When followed up at home to find out why he had left his job and not attended for $x$-ray examination, his wife described the symptoms of allergic alveolitis while explaining why he had changed his work and how these symptoms had abated since leaving. He refused further investigation.

In addition to this man 10 other maltmen (including five who worked at the site of the original outbreak) were found to have precipitating antibodies in their serum against the $A$. clavatus antigen. The sera of 6 of these 10 men cross-reacted with the other antigens. Of the 11 men with precipitins, 7 had symptoms of chronic respiratory illness and 5 complained of symptoms late in the day after work (Table 1). Two men (H.G. and A.C.), the first of whom was a heavy smoker, had the symptoms and associated clinical signs of chronic bronchitis. They had worked in the industry for 18 and 25 years respectively.

TABLE 1

Summary of Data on 11 Men with Precipitins against Aspergillus clavatus Antigen

\begin{tabular}{|c|c|c|c|c|c|c|c|c|c|c|c|c|c|}
\hline & \multirow[t]{2}{*}{ Age } & \multirow{2}{*}{$\begin{array}{c}\text { Length } \\
\text { of service } \\
(y r)\end{array}$} & \multirow{2}{*}{$\begin{array}{c}\text { Smoking } \\
\text { habits } \\
\text { (cigs./day) }\end{array}$} & \multirow{2}{*}{$\begin{array}{l}\text { Chronic } \\
\text { respiratory } \\
\text { symptoms }\end{array}$} & \multicolumn{2}{|c|}{$\begin{array}{c}\text { Respiratory } \\
\text { symptoms } \\
\text { at work }\end{array}$} & \multicolumn{2}{|c|}{$\begin{array}{c}\text { History of } \\
\text { atopy }\end{array}$} & \multicolumn{4}{|c|}{ Precipitins present } & \multirow{2}{*}{ FEV } \\
\hline & & & & & Early & Late & Personal $F$ & Family & $\begin{array}{c}\text { A. } \\
\text { clavatus }\end{array}$ & $\begin{array}{c}P . \\
\text { granulatum }\end{array}$ & $\begin{array}{c}P . \\
\text { citrinum }\end{array}$ & $\begin{array}{c}R h . \\
\text { stolonifer }\end{array}$ & \\
\hline $\begin{array}{l}\text { T.L. } \\
\text { J.C. }\end{array}$ & $\begin{array}{l}47 \\
37\end{array}$ & $\begin{array}{r}14 \\
3\end{array}$ & $\begin{array}{l}\text { None } \\
20\end{array}$ & $\begin{array}{l}+ \\
+\end{array}$ & - & $\begin{array}{l}+ \\
+\end{array}$ & $\overline{-}$ & + & $\begin{array}{l}+ \\
+\end{array}$ & $\begin{array}{l}+ \\
+\end{array}$ & - & + & \\
\hline $\begin{array}{l}\text { G.B. } \\
\text { J.B. }\end{array}$ & $\begin{array}{l}30 \\
31\end{array}$ & $\begin{array}{l}2 \\
4\end{array}$ & $\begin{array}{l}15 \\
20\end{array}$ & + & \pm & \pm & $\begin{array}{l}- \\
-\end{array}$ & $\begin{array}{l}+ \\
+\end{array}$ & + & + & - & + & 80 \\
\hline $\begin{array}{l}\text { J.C. } \\
\text { G.S. }\end{array}$ & $\begin{array}{l}22 \\
22\end{array}$ & $\begin{array}{l}3 \\
1\end{array}$ & $\begin{array}{l}\text { None } \\
30\end{array}$ & - & - & - & - & $\overline{+}$ & + & - & $\overline{-}$ & - & \\
\hline $\begin{array}{l}\text { H.G. } \\
\text { D.G. }\end{array}$ & $\begin{array}{l}48 \\
42\end{array}$ & $\begin{array}{l}18 \\
15\end{array}$ & $\begin{array}{l}30 \\
20\end{array}$ & + & \pm & $\begin{array}{l}- \\
+\end{array}$ & + & \pm & $\begin{array}{l}+ \\
+\end{array}$ & $\begin{array}{l}+ \\
+\end{array}$ & - & + & \\
\hline $\begin{array}{l}\text { J.M. } \\
\text { J.A. }\end{array}$ & $\begin{array}{l}29 \\
64\end{array}$ & $\begin{array}{r}6 \\
35\end{array}$ & $\begin{array}{l}20 \\
\text { Past }\end{array}$ & - & - & $\begin{array}{l}- \\
-\end{array}$ & - & $\begin{array}{l}+ \\
+\end{array}$ & $\begin{array}{l}+ \\
+\end{array}$ & $\begin{array}{l}+ \\
+\end{array}$ & - & - & \\
\hline A.C. & 46 & 28 & 15 & + & - & + & + & - & + & - & - & - & 8 \\
\hline
\end{tabular}


Sixty-eight of the 114 maltmen were found to have precipitating antibodies against the four antigens chosen but none of the sera collected from 25 carpet workers reacted with these antigens. Only 14 of 100 additional control sera collected at a paper factory reacted with the $R h$. stolonifer antigen (Table 2). However, when these data were related

TABLE 2

Prevalence of Positive Serology

\begin{tabular}{l|ccc}
\hline \multicolumn{1}{c|}{ Precipitins $^{1}$} & Maltworkers & $\begin{array}{c}\text { Carpet } \\
\text { workers }\end{array}$ & $\begin{array}{c}\text { Paper } \\
\text { workers }\end{array}$ \\
\hline Present & 68 & 0 & 14 \\
Absent & 46 & 25 & 86 \\
\hline Total & 114 & 25 & 100 \\
\hline
\end{tabular}

1against one or several of the four antigens chosen.

to the prevalence of respiratory illness (Table 3) the proportion of men with precipitins in their serum did not differ significantly from those without symptoms, nor were any significant differences found when the serological data were compared with the other reference data chosen.

TABLE 3

Chronic Respiratory Symptoms and Precipitins AgAinst MOUld ANTIGENS AMONG MALTWORKERS

\begin{tabular}{l|cc|c}
\hline \multirow{2}{*}{\multicolumn{1}{c|}{ Precipitins }} & \multicolumn{3}{|c}{ Respiratory symptoms } \\
\cline { 2 - 4 } & Present & Absent & Total \\
\hline Present & 33 & 35 & 68 \\
Absent & 27 & 19 & 46 \\
\hline Total & 60 & 54 & 114 \\
\hline
\end{tabular}

$\chi^{2}=1 \cdot 32 ; \mathrm{P}>0.50$

When the prevalence of respiratory symptoms among the maltworkers was compared with that among the carpet workers, there was a significant increase in symptoms among the maltworkers $\left(\chi^{2}=\right.$ 8.357; $\mathrm{P}<0.02$ ) (Table 4). Unfortunately the carpet workers did not strictly match the maltworkers in age and length of service and for this reason these observations are open to question.

As expected the prevalence of respiratory symptoms increased as the age of maltworkers increased and there was also an apparent increased prevalence with length of service (Table 5). However, this latter finding could equally have been due to the increasing age of the men.
TABLE 4

Prevalence of Respiratory Symptoms among MALTWORKERS AND CARPETWORKERS

\begin{tabular}{l|cc|c}
\hline & $\begin{array}{c}\text { Malt- } \\
\text { workers }\end{array}$ & $\begin{array}{l}\text { Carpet } \\
\text { workers }\end{array}$ & Total \\
\hline Present & 60 & 5 & 65 \\
Absent & 54 & 20 & 74 \\
\hline Total & 114 & 25 & 139 \\
\hline
\end{tabular}

$\chi^{2}=8.357 ; \mathrm{P}<0.02>0.01$

TABLE 5

Prevalence of Respiratory Symptoms in MaltWORKERS IN RELATION to LENGTH OF SERVICE

\begin{tabular}{l|ccc|c}
\hline \multirow{2}{*}{ Symptoms } & \multicolumn{5}{|c|}{ Length of service $(y r)$} \\
\cline { 2 - 5 } & $1^{1}-6$ & $7-17$ & $18-43$ & Total \\
\hline Present & 16 & 19 & 25 & 60 \\
Absent & 21 & 18 & 12 & 51 \\
\hline & 37 & 37 & 37 & 111 \\
\hline
\end{tabular}

$\chi^{2}=4 \cdot 18 ; \mathrm{P}<0.2>0 \cdot 1$

${ }^{1}$ Three men had worked for less than one year and were excluded from this and Table 6.

Though the prevalence of chronic respiratory symptoms increased with the number of cigarettes smoked, the differences while suggestive were not significant. This apparent absence of cause and accepted effect was also noted in another survey (Channell et al., 1969).

When other conditions, which might also be expected to contribute to an increase in respiratory illness, were considered, three factors were noteworthy. The first was the statistically significant decrease in the numbers of men with a history of atopy among the older workers in the industry (Table 6). The second was the occurrence of symptoms related to work among one-fifth of the maltworkers in contrast to none among the carpet workers. There were no significant differences between the serology of this group and the other maltworkers, nor did age, length of service, or smoking habits differ significantly. Finally, six men, five of whom were heavy smokers, complained that after cleaning 'culms' out of bins (when they were exposed to large concentrations of spores in confined spaces) they were unable to smoke during the following evening. The sixth man said his wife complained that he wheezed in bed after doing this job. These men did not obviously differ from the 
TABLE 6

History of Atopy AND Age

\begin{tabular}{l|ccc|c}
\hline \multirow{2}{*}{$\begin{array}{c}\text { History of } \\
\text { atopy }\end{array}$} & \multicolumn{4}{|c|}{ Age $(y r)$} \\
\cline { 2 - 5 } & Less than 40 & $40-49$ & 50 and older & Toials \\
\hline Present & 10 & 5 & 2 & 17 \\
Absent & 28 & 34 & 32 & 94 \\
\hline Totals & 38 & 39 & 34 & 111 \\
\hline
\end{tabular}

$x^{2}=6.111 ; \mathrm{P}<0.05>0.01$

main population in any other way. It is difficult to attach any significance to this item, but anything which stops smokers smoking is noteworthy.

\section{Discussion}

The survey data suggest that the prevalence of allergic alveolitis in the malting industry is not large. Men suffering from acute allergic alveolitis are very ill, and the paucity of reported cases in the literature (Vallery-Radot and Giroud, 1928; Riddle et al., 1968; Channell et al., 1969) supports this view. However, a similar incident (Shawyer, 1969, personal communication) in another maltings contaminated by $A$. clavatus was only recognized in retrospect when the two affected maltmen were reinvestigated, and this suggests that some cases may pass unrecognized. Also, Mickolczy (1958) attributed a respiratory illness among Hungarian maltworkers to the physical properties of the dust inhaled rather than to the many mould spores present, and Filip and Barborik (1966) considered a similar illness among mainly female Czechoslovakian maltworkers to be a mycosis. With increasing awareness of this condition no doubt further instances will be reported.

Management and the workers should be aware of the potential danger of the situation described by Vallery-Radot and Giroud (1928) and Riddle et al. (1968). Fortunately these situations, when the barley being malted at high ambient temperatures contains damaged or split corns and is contaminated with mould, constitute something of a malting disaster and to this extent are avoided by the industry. When these dangerous conditions arise, the men should be protected by the use of effective face masks or the malting should be stopped until conditions improve.

Though Thackrah (1832) drew attention to the occurrence and severity of respiratory disease among maltworkers who were exposed to sulphurous fumes and dust as they turned malt in the kilns, and the Factory Inspectorate (McNair and Middleton, 1925) reported respiratory symptoms among maltsters screening malt contaminated by spores of
Rhizopus nigricans, the present survey does not suggest that chronic respiratory illness is a major problem in the malting industry but it poses some questions.

The prevalence of respiratory symptoms among the maltworkers was significantly greater than among the controls. The controls sorting and carding wool worked in very dusty conditions and, though not strictly comparable in age or length of service, and having different smoking habits, these groups were two distinct working populations. In addition, while no controls complained, one-fifth of the maltworkers were aware of respiratory symptoms at or after work.

Pepys, Longbottom, and Jenkins (1964) have drawn attention to the wide variety of organic antigens which stimulate antibody production on inhalation, and the potential of mould spores to produce potent antigens is emphasized by the positive serology found among the maltworkers. The lack of any correlation between these serological results and the other data was perhaps disappointing, but the absence of precipitins among the controls cannot be ignored and it does indicate that the maltmen are potentially at risk. It is possible that the moulds arbitrarily chosen because of the limited nature of this investigation were not the important antigens.

The significant decrease in the number of older men giving a history of atopy raises the possibility that these individuals are leaving the industry by self-selection because they are physically unsuitable, and if this were confirmed there would be a case for excluding men with such a history from the industry.

Pepys (1969) has drawn attention to episodes of bronchospasm in non-atopic subjects having precipitins with a delay in onset after exposure to antigens similar to that in allergic alveolitis. The present survey did not reveal any illness of this nature, but many of the men who complained of symptoms after work mentioned wheezing. This observation should be checked in any future survey, and perhaps men so affected should be subjected to bronchial provocation.

On the basis of these observations, a survey on a large scale is justified. In addition to the men continuing to work in the maltings it is very important to know when and for what reasons men leave and the state of their health before and after working in the maltings.

I wish to acknowledge the encouragement and advice freely given by Dr. I. W. B. Grant, The Northern General Hospital, Edinburgh; the assistance of Dr. Peter Aitken, consultant radiologist, Victoria Hospital, Kirkcaldy in interpreting the maltmen's chest radiographs; and the consultant staff and technicians of the Fife District Laboratory, Kirkcaldy, particularly Mr. W. Melrose.

The research was financed by a grant from the Sec- 
retary of State for Scotland's Research Fund on the recommendation of the Advisory Committee for Clinical Research.

\section{References}

Channell, Sonia, Blyth, W., Lloyd, Melody, Weir, D. M., Amos, W. M. G., Littlewood, A. P., Riddle, H. F. V., and Grant, I. W. B. (1969). Allergic alveolitis in maltworkers: a clinical, mycological, and immunological study. Quarterly Journal of Medicine, 38, 351-376.

Filip, B. and Barbořik, M. (1966). Bronchopulmonálni aspergilóza. Pracovni Lékarstvi, 18, 308-310.

Longbottom, J. L. and Pepys, J. (1964). Pulmonary aspergillosis: Diagnostic and immunological significance of antigens and $\mathrm{C}$-substance in Aspergillus fumigatus. Journal of Pathology and Bacteriology, 88, 141-151.

Medical Research Council (1966). Questionary on Respiratory Symptoms (rev. ed.). W. J. Holman, Dawlish, Devon.

McNair, L. C. and Middleton, E. L. (1925). Report on dust arising in the processes of discharging and handling of grain cargoes. Annual report of the Chief Inspector of Factories and Workshops for the year 1924. Cmnd 2437, pp. 103-109. H.M.S.O., London.
Mickolczy, V. (1958). Malatalaz. Munkavédelem (Budapest), 5, 37-42.

Pepys, J. (1969). In Hypersensitivity Diseases of the Lungs Due to Fungi and Organic dusts. Kager, Basel and New York. , Longbottom, J. L., and Jenkins, P. A. (1964). Vegetable dust pneumoconioses. Immunologic responses to vegetable dusts and their flora. American Review of Respiratory Diseases, 89, 842-858.

Riddle, H. F. V. (1970). Allergic alveolitis and respiratory disease among maltworkers. M.D. thesis. University of Liverpool.

- Channell, Sonia, Blyth, W., Weir, D. M., Lloyd, Melody, Amos, W. M. G., and Grant, I. W. B. (1968). Allergic alveolitis in a maltworker. Thorax, 23, 271-280.

Thackrah, C. T. (1832). The Effects of Arts, Trades and Professions, and of Civic States and Habits of Living, on Health and Longevity. 2nd ed. Longman, Rees, Orme, Brown, Green and Longman, London.

Vallery-Radot, P. and Giroud, P. (1928). Sporomycose des pelleteurs de grains. Bulletins et Mémoires de la Société Médicale des Hôspitaux de Paris, $3^{\mathrm{e}}$ série, 52, 1632-1645.

Received for publication March 15, 1973

Accepted for publication June 11, 1973 